\title{
Effect of Mouthrinses on Water Sorption and Solubility of Flouride-Releasing Restorative Materials
}

\section{Fluorid Salabilen Restoratif Materyallerin Su Emilimi Ve Çözünürlüğü Üzerine Gargaraların Etkisi}

(D) Neslihan ÖZVEREN, iD Ezgi BALTACI, iD Sinem BATUR KARA

Trakya University Faculty of Dentistry, Department of Pediatric Dentistry, Edirne, Turkey

\begin{abstract}
Objective: This study aimed to investigate water sorption/solubility behavior of glass ionomer cement-based-containing restorative materials.

Methods: A total of 21 specimens for each material (Riva Self Cure, Riva Light Cure, GCP Glass Fill) were prepared using a teflon ring $(10 \times 2 \mathrm{~mm})$. These specimens were stored in a desiccator for 24 hours at $37 \pm 1{ }^{\circ} \mathrm{C}$ and the weight of each sample was measured using a sensitive balance. Afterwards, the specimens were stored in an incubator containing distilled water, mouthrinse with alcohol, and mouthrinse without alcohol at $37 \pm 1{ }^{\circ} \mathrm{C}$ for one day. The specimens were later dried to a constant mass in a desiccator, and each specimen was measured using a digital electronic caliper. Data were statistically analyzed $(\mathrm{p}<0.05)$.
\end{abstract}

Results: Data were evaluated using one-way ANOVA and post-hoc Tukey tests. Water sorption values were found to be significantly higher for the resin-modified glass ionomer cement group than for the high-viscosity glass ionomer cement (HVGIC) group in all the three different media $(\mathrm{p}<0.05)$. HVGIC material showed similar water sorption values for all three media.

Conclusion: Compositions of restorative materials play key roles in their water sorption/solubility in different areas.

Keywords: Glass ionomer, glass carbomer, solubility, sorption, mouthrinse

\section{ÖZ}

Amaç: Bu çalışmanın amacı, cam iyonomer siman bazlı restoratif materyallerin su emilimi ve çözünürlüğü özelliklerini araştırmaktır.

Yöntemler: Teflon halkalar (10x2 mm) kullanılarak her bir materyal (Riva Self Cure, Riva Light Cure, GCP Glass Fill) için toplam 21 örnek hazırlandı. Örnekler desikatör içerisine yerleştirilerek 24 saat $37 \pm 1{ }^{\circ} \mathrm{C}$ 'de bekletildi ve bu süre sonunda her örneğin ağırlı̆̆ terazi ile ölçüldü. Aynı örnekler daha sonra üç gruba ayrılarak bir gün boyunca distile su, alkollü gargara ve alkolsüz gargara içeren solüsyonlarda $37 \pm 1{ }^{\circ} \mathrm{C}$ 'de saklandı. Örnekler sabit bir kütleye gelinceye kadar tekrar desikatörde kurutuldu. Her örneğin çap ve kalınlıkları dijital elektronik kumpas kullanılarak ölçüldü. Veriler one-way ANOVA and post-hoc Tukey testleri kullanılarak değerlendirildi ve alfa hata düzeyi 0,05 olarak seçildi.

Bulgular: Su emilim değerleri, resin modifiye cam iyonomer siman grubu için yüksek viskoziteli cam iyonomer siman (HVGIC) grubundan üç farklı ortamın hepsinde anlamlı olarak yüksek bulunmuştur $(\mathrm{p}<0,05)$. HVGIC materyali üç ortamın tümü için benzer su emilim değerleri göstermiştir.

Sonuç: Restoratif materyallerin içerikleri, farklı alanlarda su emilim/ çözünürlüklerinde kilit rol oynar.

Anahtar Sözcükler: Cam iyonomer, cam carbomer, emilim, çözünürlük, gargara
Address for Correspondence: Neslihan ÖZVEREN, Trakya University Faculty of Dentistry, Department of Pediatric Dentistry, Edirne, Turkey

E-mail: neslihanozveren@trakya.edu.tr ORCID ID: orcid.org/0000-0002-1090-5415
Received: 17.10 .2019

Accepted: 02.02.2020

Cite this article as: Özveren N, Baltacı E, Batur Kara S. Effect of Mouthrinses on Water Sorption and Solubility of Flouride-Releasing Restorative Materials. Bezmialem Science 2021;9(1):68-74. 


\section{Introduction}

Despite advanced preventive measures, dental caries still maintains its frequency and importance among oral diseases. Dentists should choose the most appropriate restorative material based on characteristics associated with patient and caries. In addition, physical properties, biocompatibility, esthetic features, and application information of restorative materials help in making the most appropriate choice $(1,2)$.

Conventional glass ionomer cements (GIC) were developed by combining advantages of silicate and polycarboxylate cements. They have advantages such as chemical bonding to dental tissues, releasing and recharging fluoride, compatibility of thermal expansion coefficient with tooth enamel and dentin, and low cytotoxicity. Besides, GICs have disadvantages of a low wear resistance, short working time, long curing time, sensitivity to moisture contamination, and a high rate of microleakage, which limit their usage in restoration of permanent teeth and in areas that will be exposed to an occlusal force in primary teeth (3).

While the first GICs were described as being of a lower viscosity nature, later "high-viscosity" GICs (HVGIC) have been developed to improve insufficient mechanical properties and wear resistance to high occlusal forces of conventional GICs. In addition, they were produced as restorative materials to expand the areas of use restricted to Class I and Class V cavities $(3,4)$.

In order to overcome problems observed in GICs, resin-modified GIC (RMGIC) have been developed (5). Due to resin monomer polymerization, higher resistance to compressive and tensile forces, improved fracture strength, modulus of elasticity, and retention rates are reported with these materials (6,7). Working time of RMCIS is longer than that of conventional GICs. Compared to conventional GICs, RMGICs have disadvantages of weaker adhesions to dental tissues and a lower fluoride release. Increased microleakage due to polymerization shrinkage constitutes further disadvantages of the material (8).

Carbomer-based restoratives contain carbomer fillers and fluoroapatite/hydroxyapatite nanoparticles (9). Glass carbomer (GC) cements are free of monomers like resin, solvent, metal etc. and are easy to diagnose postoperatively due to their radiopacity. Moisture tolerant nature of this material makes it handy in pediatric dentistry. It is stated that pulp capping should not be performed directly with glass carbomer cements (10).

Resistance of a restorative material to intraoral conditions is very important for longevity of restorations. Water sorption and solubility features of restorative materials have a significant impact on clinical success and can not be completely controlled. Water sorption causes dimensional changes in materials, leading to discoloration and a fracture in marginal contours. Water solubility is a phenomenon that adversely affects compatibility of restorations with biological structures and increases rate of deterioration. Studies have shown that sorption and solubility of restorative materials depend on features of solutions $(1,11,12)$.

In order to prevent plaque formation in children aged $\geq 6$ years, supervised use of fluoride-based mouthrinses as well as toothpastes prevents demineralization of tooth structure and provides remineralization of early caries lesions (13).

Few studies have been conducted to evaluate effects of oral mouthrinses on the water sorption and solubility properties of restorative materials. Mouthrinses contain different concentrations of water, antimicrobial agent, salt, preservatives, and alcohol. In particular, alcohol has been reported to cause increased wear of the material $(14,15)$.

In this study, our purpose was to compare water sorption and solubility values of GC (GCP Glass Carbomer Cement), HVGIC (Riva Self Cure HV), and RMGIC (Riva Light Cure $\mathrm{HV}$ ) restorative materials in mouthrinse with alcohol (Listerine Cool Mint), mouthrinse without alcohol (Listerine Total Care Zero), and artificial saliva. The null hypothesis stated that water sorption and solubility values do not differ according to the restorative material or solvent type tested.

\section{Method}

\section{Sample Preparation}

Restorative materials used in the present study and polymerization types recommended by the manufacturer are shown in Table 1 and the solutions used in the study are shown in Table 2. Samples were prepared for each material using circular teflon molds with a diameter of $10 \mathrm{~mm}$ and a thickness of $2 \mathrm{~mm}$. The mold was isolated with petroleum jelly to prevent the materials from sticking to the mold. The materials were mixed in amalgamators at room temperature according to the manufacturer's instructions and were placed into the molds. Transparent matrix strips (Universal Strips, Extreme Dental, İstanbul, Turkey) were placed on the upper surface of the molds to overflow the surplus. The samples were polymerized according to the manufacturer's instructions. After the hardening of the material, the molds were carefully removed and the debris around them was cleaned. Twenty-one samples were prepared for each material group, which were divided into three sub-groups of seven to be placed in different solution media.

Table 1. Materials used in the study

\begin{tabular}{l|l|l}
\hline Brand & Type & Manufacturer \\
\hline Riva self cure HV & High-viscosity glass ionomer & SDI Dental, Australia \\
\hline Riva light cure HV & Resin-modified glass ionomer & SDI Dental, Australia \\
\hline Riva coat & Surface coat & SDI Dental, Australia \\
GCP glass carbomer fill & Glass carbomer & GCP Dental, Holland \\
GCP gloss & Surface coat & GCP Dental, Holland
\end{tabular}


Table 2. Solutions used in the study

\begin{tabular}{|c|c|c|c|}
\hline Solutions & Ingredients & $\begin{array}{l}\text { Alcohol } \\
\text { percentage }\end{array}$ & $\mathrm{pH}$ \\
\hline $\begin{array}{l}\text { Listerine Cool Mint (Johnson \& } \\
\text { Johnson, İstanbul, Turkey) }\end{array}$ & $\begin{array}{l}\text { Thymol } 0.064 \% \text {, eucalyptol } 0.092 \% \text {, methyl salicylate } 0.060 \% \text { and } \\
\text { menthol } 0.042 \% \text {. water, alcohol } 21.6 \% \text {, sorbitol solution, flavoring, } \\
\text { poloxamer } 407 \text {, benzoic acid, sodium saccharin, sodium benzoate, and FD } \\
\text { \& C green. }\end{array}$ & $21.6 \%$ & 3.92 \\
\hline $\begin{array}{l}\text { Listerine Total Care Zero } \\
\text { (Johnson \& Johnson, İstanbul, } \\
\text { Turkey) }\end{array}$ & $\begin{array}{l}\text { Eucalyptol } 0.091 \% \text {, menthol } 0.042 \% \text {, thymol } 0.063 \% \text {, sodium fluoride } \\
0.022 \% \text {, zinc chloride } 0.09 \% \text {, aroma (flavor), benzoic acid, blue } 1 \text {, methyl } \\
\text { salicylate, poloxamer } 407 \text {, propylene gly-col, Red } 1 \text {, sodium benzoate, } \\
\text { sodium lauryl sulfate, sodium saccharin, sorbitol, su-cralose, water }\end{array}$ & - & 6.02 \\
\hline Artificial Saliva & $4.8 \mathrm{mM} \mathrm{NaCl}, 137 \mathrm{mM} \mathrm{KCl}, 1.5 \mathrm{mM} \mathrm{CaCl}_{2}, 8.2 \mathrm{mM} \mathrm{NaHCO}_{3}, 4.0 \mathrm{mM} \mathrm{KH}_{2} \mathrm{PO}_{4}$ & - & 7.4 \\
\hline
\end{tabular}

Table 3. Sorption values of materials in different environments and statistical evaluation of the groups

\begin{tabular}{|c|c|c|c|c|}
\hline Water sorption $\left(\mu \mathrm{g} / \mathrm{mm}^{3}\right)$ & Artifical Saliva & Mouthrinse with alcohol & Mouthrinse without alcohol & $p^{\prime \prime}$ \\
\hline HVGIC & $70.1 \pm 5.9(A, 1)$ & $63.6 \pm 3.4(A, 1)$ & $68.7 \pm 4.8(A, 1)$ & $p=0.123$ \\
\hline RMGIC & $131.5 \pm 7.4(B, 1)$ & $89.4 \pm 4.7(B, 2)$ & $119.1 \pm 3.5(B, 3)$ & $\begin{array}{l}<0.001 \\
=0.001 \\
<0.001\end{array}$ \\
\hline GC & 148.9 & $92.3 \pm 18.6$ & $101.9 \pm 7.3$ & \\
\hline
\end{tabular}

Table 4. Solubility of materials in different environments and statistical evaluation of the groups

\begin{tabular}{|c|c|c|c|c|}
\hline Solubility $\left(\mu \mathrm{g} / \mathrm{mm}^{3}\right)$ & Artifical Saliva & Mouthrinse with alcohol & Mouthrinse without alcohol & $p^{\prime \prime}$ \\
\hline HVGIC & $4.1 \pm 3.8(\mathrm{~A}, 1)$ & $23.3 \pm 2.8(\mathrm{~A}, 2)$ & $16.2 \pm 3.8(\mathrm{~A}, 2)$ & $\begin{array}{l}p<0.001, \\
p=0.006, \\
p=0.206\end{array}$ \\
\hline RMGIC & $30.0 \pm 6.6(B, 1)$ & $31.4 \pm 4.3(\mathrm{~A}, 1)$ & $34.5 \pm 6.1(B, 1)$ & $p=0.480$ \\
\hline GC & -11.9 & $42.3 \pm 42.7$ & $-14.0 \pm 3.0$ & \\
\hline $\mathrm{p}^{*}$ & $p<0.001$ & $p=0.114$ & $\mathrm{p}<0.001$ & \\
\hline
\end{tabular}

Letters and numbers are used to indicate differences in the columns and rows, respectively.

*p values represent comparison results between HVGIC and RMGIC materials

The three $p$ values represent comparison results between the artificial saliva and mouthrinse with alcohol, artificial saliva and mouthrinse without alcohol, mouthrinse with alcohol and mouthrinse without alcohol environments, respectively.

HVGIC: High-viscosity glass ionomer cement, RMGIC: Resin-modified glass ionomer cement, GC: Glass carbomer

\section{Sorption and Solubility Measurements}

All samples were stored in a desiccator with an anhydrous self-indicating silica gel at $37 \pm 1^{\circ} \mathrm{C}$ for 24 hours. Then, the initial weights of the samples were measured on an electronic analytical balance (brand) as micrograms $(\mu \mathrm{g})$ and recorded as $m \mathrm{~L}$. The samples were suspended in different solutions according to their groups for 24 hours at $37^{\circ} \mathrm{C}$. Subsequently, the samples were removed from the solutions and their weights were measured one minute after removal and recorded as $m 2$. After the measurement process, the samples were placed again in the desiccator for 24 hours to evaporate the water content and, subsequently, their weights were measured and recorded as $m 3$. The volumes of the samples were found in $\mathrm{mm} 3$ according to the formula $V=\pi \times r^{2} \mathrm{xh}$, where $r$ is the radius of the average diameter/2 and $\mathrm{h}$ is the average thickness. Then, the water sorption and solubility of the samples were found in $\mu \mathrm{g} / \mathrm{mm}^{3}$ with the formulas $m 2-m 3 / V$ and $m 1-m 3 / V$, respectively. 


\section{Statistical Analysis}

The IBM SPSS Statistics 20 program was used to perform statistical tests with a significance level set at $5 \%$. Besides, descriptive statistics, one-way ANOVA, and post-hoc Tukey tests were used to compare means of sorption and solubility between the groups.

\section{Results}

The mean water sorption and solubility values for each material and medias used in the study are shown in Tables 3 and 4, respectively. Also, in Figure 1, both the mean water sorption and solubility values were presented for each material at different media.

The glass carbomer materials used in the study were mostly found to be fragmented. Only 1, 3, and 2 sound samples were left to be measured for the artificial saliva, mouthrinse with alcohol and mouthrinse without alcohol groups, respectively. Although the results of this group are shown in the tables, they were not included in the statistical analysis due to the small number of samples.

Water sorption values were found to be significantly higher for the RMGIC group compared to the HVGIC group in all the three different media $(p<0.001)$. HVGIC material showed similar water sorption values for all the three media $(\mathrm{p}=0.123)$. However, RMGIC material showed the highest sorption in artificial saliva, which was followed by the mouthrinse without alcohol and mouthrinse with alcohol, respectively $\left(\mathrm{p}_{\text {saliva-with alcohol }}\right.$ $\left.<0.001, \mathrm{p}_{\text {saliva-without alcohol }}=0.001, \mathrm{p}_{\text {with alcohol-without alcohol }}<0.001\right)$.

Solubility values were significantly lower in the HVGIC group compared to the RMGIC group in artificial saliva $(p<0.001)$ and mouthrinse without alcohol environments $(p<0.001)$, but no significant difference was found in the mouthrinse with alcohol environment $(\mathrm{p}=0.114)$. While RMGIC showed similar solubility in all three environments $(\mathrm{p}=0.480)$, the HVGIC material showed significantly lower solubility in artificial saliva

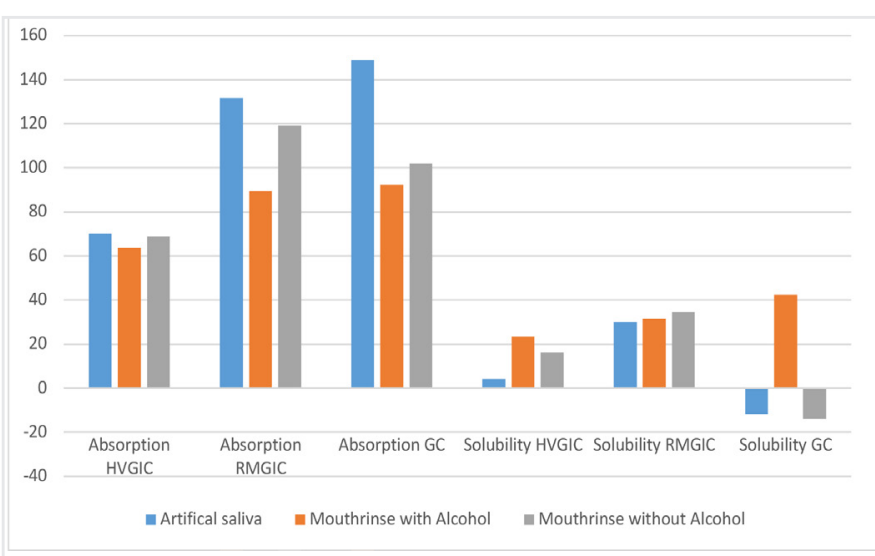

Figure 1. Average sorption and solubility values for materials in different media

HVGIC: High-viscosity glass ionomer cement, RMGIC: Resinmodified glass ionomer cement, GC: Glass carbomer compared to other media $\left(\mathrm{p}_{\text {saliva-with alcohol }}<0.001, \mathrm{p}_{\text {saliva-without alcohol }}\right.$ $\left.=0.006, \mathrm{p}_{\text {with alcohol-without alcohol }}=0.206\right)$.

\section{Discussion}

Due to esthetic properties, polymer-based materials are used in dental restorations, but hydrophilic properties of these materials result in some degree of water sorption or dissolution in these materials (16). Water sorption and dissolution have been reported to adversely affect the clinical success of these restorations $(17,18)$.

Conventional GICs are restorative materials that can easily draw water into their structures. It is very necesaary to investigate water sorption and solubility levels of restorative materials in order to increase clinical success rate of restorations and determine their application areas (19). In conventional GIC, water sorption occurs primarily within the matrix. Due to the water sorption, hydrolysis of the cement matrix occurs. Cement mass deteriorates over time and loss of surface properties, marginal integrity, esthetic appearance, and consequent deterioration in restorations occur (5). To overcome well-known disadvantages of GICs, RMGICs and high-viscosity GICs have been developed. While there are many studies evaluating the physical properties of high-viscosity GICs in the literature, the studies evaluating water sorption and solubility are limited $(11,20-22)$. In previous studies, the sample dimensions were chosen to be $10-15 \mathrm{~mm}$ in diameter and $1-4 \mathrm{~mm}$ in thickness. Sample sizes are effective in diffusion of water to the polymer matrix. Smaller sample size shortens stabilization time in the material $(23,24)$. The diameter of the specimens used in our study was prepared as $10 \mathrm{~mm}$ according to diameter of the tip of the light curing device, and the thickness was selected as $2 \mathrm{~mm}$ according to the layering method. There are studies with just one-hour storage solutions as well as one-year storage solutions to assess water sorption and solubility $(25,26)$. Residence time is known to affect water sorption and solubility levels of the materials. Since it is known that $\mathrm{pH}$ changes may affect diffusion and solubility, the residence time used in our study was chosen as 24 hours to prevent variations in $\mathrm{pH}$. In order to determine water sorption and solubility of the materials, different formulas are used in different studies (27-34). We used the formulas prepared under the guidance of the ISO standard in our study. All these methodological differences (sample size, solution storage time, formulation of the water sorption, and solubility) may have a role in the result inconsistencies in the literature.

RMGIC materials have been reported to exhibit higher water sorption and solubility than composites (35). It has also been reported that RMGIC materials have a higher and faster water sorption than conventional GIC materials (28). In another study, RMGIC materials showed similar or higher sorption values than HVGIC materials (33).

It has been claimed that high water sorption of RMGIC is caused by the initial desiccation procedure, which disrupts acid-base reactions (30). Another suggestion is that polycarboxylic acid, inorganic glass particles, and HEMA contained in RMGIC 
structure retain large amounts of water (28). In our study, based on existing literature, the water sorption values were significantly lower in all the three solution environments for the HVGIC group compared to the RMGIC group. In solubility values, it was observed that the HVGIC group showed less dissolution than the RMGIC, except in the alcohol-free mouthrinse group. With increasing concerns about more effective oral hygiene habits, particularly with regard to the pediatric population, the use of chemical control agents (e.g., mouthwashes) has been adopted to complement toothbrushing and dental flossing (36). Their composition is based on water, antimicrobial agents, salts, preservatives, alcohol, and hydrogen peroxide (37). It has been reported that mouthrinses, containing alcohol or not, can increase the sorption and solubility for restorative materials compared to distilled water, but this effect may vary according to the material tested $(29,31,32)$. In our study, the HVGIC material showed a significantly lower solubility in the artificial saliva environment than in other environments as expected, because mouthwashes trigger a decrease in the oral $\mathrm{pH}$, which has been associated with an increase in the solubility of dental materials $(38,39)$. However, RMGIC showed similar solubility in all the three environments, which may be explained by its already high solubility in artifical saliva due to its hydrophilicity. The sorption values of the RMGIC material were higher in the mouthrinse without alcohol environment than in the mouthrinse with alcohol environment. Also in artificial saliva environment RMGIC showed highest sorption values. These results may be due to the rapid water sorption of HEMA, a significant resin component found in the RMGIC material. In the HVGIC group, there was no difference between the two mouthrinses and artificial saliva environments in terms of sorption. Contrary to previous studies $(37,40)$, mouthrinses did not increase the sorption of the HVGIC materials used in the present study, which may be explained by the more resistant structure of these materials to the chemical ingredients of the mouthrinses $(41,42)$.

Savas et al. (33) and Subramaniam et al. (34) evaluated water solubility of GC in their study and reported that it is lower than conventional GICs. They did not mention fragmentation as in our study $(33,34)$. In the present study, after the fragmentation of GC samples, new specimens were prepared by applying a surface covering on the GC materials, but sample loss due to serious fragmentation was experienced again.

Subramaniam et al. (34) modified the section 7.12 of ISO 4049 by placing specimens in a solution of artificial saliva immediately after preparation. They claimed that desiccation might affect the glass ionomer specimens' water sorption and solubility results due to damage (30). The reason for the disintegration of our GC samples may be bacause they were placed in a desiccator immediately after curing and removal from the mold as described in section 7.12 of ISO 4049 .

\section{Study Limitations}

The main limitations of this study are in vitro design and the use of arguably shorter time periods to test water sorption and solubility. Clinical studies must be conducted to confirm the results.

\section{Conclusion}

High-viscosity GIC and RMGIC materials show significant water sorption and solubility; especially, RMGIC materials perform poorly in terms of sensitivity to water and this may cause degradation in the oral environment. Whether it contains alcohol or not, mouthwashes may have an adverse effect on the material structure by increasing sorption of RMGICs and solubility of GICs.

Further long-term studies are needed to investigate the sorption and solubility characteristics of these fluoride-releasing restorative materials.

Peer-review: Externally peer reviewed.

\section{Authorship Contributions}

Surgical and Medical Practices: E.B., S.B.K., Concept: N.Ö., Design: N.Ö., Data Collection or Processing: N.Ö., E.B. Analysis or Interpretation: N.Ö. Literature Search: N.Ö., S.B.K., Writing: N.Ö.

Conflict of Interest: No conflict of interest was declared by the authors.

Financial Disclosure: The authors declared that this study received no financial support.

\section{References}

1. Bhatia HP, Singh S, Sood S, Sharma N. A Comparative Evaluation of Sorption, Solubility, and Compressive Strength of Three Different Glass Ionomer Cements in Artificial Saliva: An in vitro Study. Int J Clin Pediatr Dent 2017;10:49-54.

2. Terry DA, Leinfelder KF, Maragos C. Developing form, function, and natural aesthetics with laboratory-processed composite resin-Part I. Pract Proced Aesthet Dent 2005;17:313-8; quiz 320.

3. Naasan M, Watson T. Conventional glass ionomers as posterior restorations. A status report for the American Journal of Dentistry. Am J Dent 1998;11:36-45.

4. Gao W, Peng D, Smales RJ, Yip KH-K. Comparison of atraumatic restorative treatment and conventional restorative procedures in a hospital clinic: evaluation after 30 months. Quintessence Int 2003;34:31-7.

5. Rosenstiel SF, Land MF, Crispin BJ. Dental luting agents: A review of the current literature. J Prosthet Dent 1998;80:280-301.

6. Mitra SB, Kedrowski BL. Long-term mechanical properties of glass ionomers. Dent Mater 1994;10:78-82.

7. Uno S, Finger WJ, Fritz U. Long-term mechanical characteristics of resin-modified glass ionomer restorative materials. Dent Mater 1996;12:64-9.

8. Çapan BŞ, Akyüz S. Current fluoride-releasing restorative materials used in pediatric dentistry. Clin Exp Health Sci 2016;6:129-34. 
9. Koenraads H, Van der Kroon G, Frencken J. Compressive strength of two newly developed glass-ionomer materials for use with the Atraumatic Restorative Treatment (ART) approach in class II cavities. Dent Mater 2009;25:551-6.

10. Algera TJ, Kleverlaan CJ, Prahl-Andersen B, Feilzer AJ. The influence of environmental conditions on the material properties of setting glass-ionomer cements. Dent Mater 2006;22:852-6.

11. Hinoura K, Onose H, Masutani S, Matsuzaki T, Moore B. Volumetric change of light cured glass ionomer in water. J Dent Res 1993;72:222.

12. Soderholm KJ, Zigan M, Ragan M, Fischlschweiger W, Bergman M. Hydrolytic degradation of dental composites. J Dent Res 1984;63:1248-54.

13. Burt BA. Prevention policies in the light of the changed distribution of dental caries. Acta Odontol Scand 1998;56:179-86.

14. Aguiar FHB, Lima DANL, Paulillo LAMS, Lovadino JR. Effect of light curing modes and ethanol immersion media on the susceptibility of a microhybrid composite resin to staining. J Appl Oral Sci 2007;15:105-9.

15. Cavalcanti AN, Mitsui F, Ambrosano G, Mathias P, Marchi GM. Effect of different mouthrinses on Knoop hardness of a restorative composite. Am J Dent 2005;18:338-40.

16. Ito S, Hashimoto M, Wadgaonkar B, Svizero N, Carvalho RM, Yiu $\mathrm{C}$, et al. Effects of resin hydrophilicity on water sorption and changes in modulus of elasticity. Biomaterials 2005;26:6449-59.

17. Lopes LG, Cefaly DF, Franco EB, Mondelli RF, Lauris JR, Navarro MF. Clinical evaluation of two" packable" posterior composite resins: two-year results. Clin Oral Investig 2003;7:123-8.

18. Witzel MF, Calheiros FC, Gonçalves F, Kawano Y, Braga RR. Influence of photoactivation method on conversion, mechanical properties, degradation in ethanol and contraction stress of resinbased materials. J Dent 2005;33:773-9.

19. Küçükeşmen HC, Küçükeşmen Ç, Öztaş D, Kaplan R. Farklı Tiplerdeli Geleneksel ve Rezin-Modifiye Cam İyonomer Simanların Su Emilimi ve Suda Çözünürlüğü. A.Ü. Diş Hek. Fak. Derg 2005;32:25-34.

20. Salinovic I, Stunja M, Schauperl Z, Verzak Z, Ivanisevic Malcic A, Brzovic Rajic V. Mechanical Properties of High Viscosity Glass Ionomer and Glass Hybrid Restorative Materials. Acta Stomatol Croat 2019;53:125-31.

21. Bonifacio CC, Kleverlaan CJ, Raggio DP, Werner A, de Carvalho RC, van Amerongen WE. Physical-mechanical properties of glass ionomer cements indicated for atraumatic restorative treatment. Aust Dent J 2009;54:233-7.

22. Yamakami SA, Ubaldini ALM, Sato F, Medina Neto A, Pascotto RC, Baesso ML. Study of the chemical interaction between a high-viscosity glass ionomer cement and dentin. J Appl Oral Sci 2018;26:e20170384.

23. Al Sunbul H, Silikas N, Watts DC. Resin-based composites show similar kinetic profiles for dimensional change and recovery with solvent storage. Dent Mater 2015;31:e201-e17.

24. Archegas L, Caldas D, Rached RN, Vieira S, Souza EM. Sorption and solubility of composites cured with quartz-tungsten halogen and light emitting diode light-curing units. J Contemp Dent Pract 2008;9:7380.

25. Alshali RZ, Salim NA, Satterthwaite JD, Silikas N. Long-term sorption and solubility of bulk-fill and conventional resin-composites in water and artificial saliva. J Dent 2015;43:1511-8.

26. Palin W, Fleming G, Burke F, Marquis P, Randall R. The influence of short and medium-term water immersion on the hydrolytic stability of novel low-shrink dental composites. Dent Mater 2005;21:852-63.

27. Rahim TNAT, Mohamad D, Akil HM, Ab Rahman I. Water sorption characteristics of restorative dental composites immersed in acidic drinks. Dent Mater 2012;28:e63-e70.

28. Cattani-Lorente M-A, Dupuis V, Payan J, Moya F, Meyer J-M. Effect of water on the physical properties of resin-modified glass ionomer cements. Dent Mater 1999;15:71-8.

29. Değer C, Kari P, Müjdeci A. Kompozir Rezinlerin Su Emilimi ve Çözünürlüğü Üzerine Gargaraların Etkisi. A.Ü. Diş Hek. Fak. Derg 2017;44:129-39.

30. Gerdolle DA, Mortier E, Jacquot B, Panighi MM. Water sorption and water solubility of current luting cements: An in vitro study. Quintessence Int 2008;39:e107-14.

31. Leal JP, da Silva JD, Leal RFM, Oliveira-Júnior CdC, Prado VLG, Vale GC. Effect of Mouthwashes on Solubility and Sorption of Restorative Composites. Int J Dent 2017;2017:5865691.

32. Ozer S, Sen Tunc E, Tuloglu N, Bayrak S. Solubility of two resin composites in different mouthrinses. Biomed Res Int 2014;2014:580675.

33. Savas S, Colgecen O, Yasa B, Kucukyilmaz E. Color stability, roughness, and water sorption/solubility of glass ionomer-Based restorative materials. Niger J Clin Pract 2019;22:824-32.

34. Subramaniam P, Girish Babu K, Jayasurya S. Evaluation of solubility and microleakage of glass carbomer sealant. J Clin Pediatr Dent 2015;39:429-34.

35. Akman H, Tosun G, Kahvecioğlu F. Kütlesel olarak yerleştirilebilen restoratif materyallerin su emilimi ve suda çözünürlük özelliklerinin değerlendirilmesi. Selcuk Dent J 2018;5:13-21

36. Perala SR, Bhupathiraju P. Efficacy of Four Fluoride Mouth Rinses on Streptococcus mutans in High Caries Risk Children - A Randomized Controlled Trial. J Clin Diagn Res 2016;10:ZC56-ZC60.

37. Armas-Vega A, Casanova-Obando P, Taboada-Alvear MF, Aldas-Ramirez JE, Montero-Oleas N, Viteri-Garcia A. Effect of mouthwashes on the integrity of composite resin and resin modified glass ionomer: In vitro study. J Clin Exp Dent 2019;11:e179-e84.

38. Trauth KG, Godoi AP, Colucci V, Corona SA, Catirse AB. The influence of mouthrinses and simulated toothbrushing on the surface roughness of a nanofilled composite resin. Braz Oral Res 2012;26:209-14.

39. Jyothi K, Crasta S, Venugopal P. Effect of five commercial mouth rinses on the microhardness of a nanofilled resin composite restorative material: An in vitro study. J Conserv Dent 2012;15:214-7.

40. da Silva AB, Raposo NM, Gomes IA, Goncalves LM, Paschoal MA. In vitro quantitative comparison of erosive potential of 
infant mouthwashes on glass ionomer cement. J Clin Exp Dent 2018;10:e206-e11.

41. Toledano M, Osorio R, Osorio E, Aguilera FS, Romeo A, de la Higuera B, et al. Sorption and solubility testing of orthodontic bonding cements in different solutions. J Biomed Mater Res B Appl Biomater 2006;76:251-6.
42. Kielbassa AM, Glockner G, Wolgin M, Glockner K. Systematic review on highly viscous glass-ionomer cement/resin coating restorations (Part I): Do they merge Minamata Convention and minimum intervention dentistry? Quintessence Int 2016;47:813-23. 